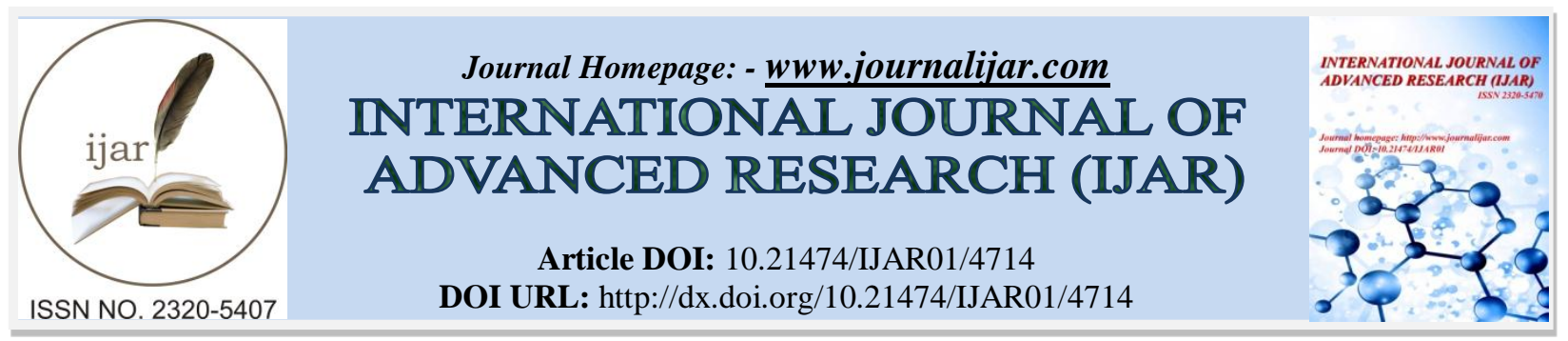

RESEARCH ARTICLE

\title{
THE INFLUENCE OF TAREKAT SYATTARIYAH TOWARD POLITICAL AND SOCIAL ASPECTS IN THE REGENCY OF NAGAN RAYA, ACEH-INDONESIA.
}

\begin{abstract}
Abdul Manan.
Universitas Islam Negeri (UIN) Ar-Raniry Darussalam, Banda Aceh-Indonesia.

\section{Manuscript Info}

(.........................

Manuscript History

Received: 3 May 2017

Final Accepted: 5 June 2017

Published: July 2017

Key words:-

Tarekat Syattariyah, Nagan Raya,

Politic.

\section{Abstract}

Tarekat (the order of Islamic mysticism) had significant role upon the Islamic life of the people in Indonesia. In certain area, tarekat became an interesting phenomenon since the mursyid (guiding teacher) and several of its followers possessed certain authorities as the member on official governance or even the leader of a region. This research studied the influence of Tarekat Syattariyah (the order of Islamic mysticism of Syattariyah) toward political and social aspects in Nagan Raya. This study describe the participation of Tarekat Syatariah on the regional election in Nagan Raya along with its triumph during the period of 2002-2006, 2006-2012, an 2012-2017, and factors causing fails in the election in 2017 that was considered as the beginning of fall it in the governance. This research was conducted by using qualitative approach as an ethnographic study that employed three data collecting technics: interview, observation, and document study. The result indicated that the Tarekat Syattariyah was actively involved in the political activities in the Nagan Raya Regency and had significant influence on legislative and executive governance. Since the establishment of this regency in 2002 until 2017, Nagan Raya was led by regent who closely related to the Tarekat Syattariyah. The regent even led Nagan Raya for three periods respectively. However, in 2017, this Tarekat failed winning the regional election since it had lost the people's reliance due to nepotism, which had been done during the era of their governance.
\end{abstract}

Copy Right, IJAR, 2017,. All rights reserved.

\section{Introduction:-}

Several studies and historical fact noted that the existence of Sufi (Islamic mysticism) and Tarekat (the order of Islamic Mysticism) had significant role toward the development of Islam in the entire of world. Misri A. Muchsin stated that several experts agreed about significant role of Sufi toward the history of endeavor of Islam in Africa, India and Southeast Asia, particularly a century after the Prophet Muhammad p.b.u.h. had passed away. ${ }^{1}$

Oman Fathurrahman explained "In the context of Malay-Indonesia, Tarekat had important role, since Islam that was introduced within this area had the influence of Tasawuf; thus, the organizations of Tasawuf were existed in the area

${ }^{1}$ Misri A. Muchsin, Dinamika Tasawuf di Aceh Pada Abad Ke 20, Kajian Sejarah, Sosial dan Keagamaan, Cet 1, Banda Aceh: Ar-Raniry Press dan Lembaga Naskah Aceh (NASA), 2012, p. 1 
of Malay and Indonesia". ${ }^{2}$ These opinions made us realized the role of Sufi in the development of Islam, particularly on the introduction of Islam in the area of Southeast Asia, especially in Indonesia.

In Aceh, several orders of Islamic mysticism also developed, which focused on the activity of worship and became near to Allah. The orders of Islamic mysticism existing in Aceh included Tarekat Syattariyah, Tarekat Nasabandiyah, Tarekat Qadariyah and so on. According to historical notes, the development of Tarekat Syattariyah was associated on the period when Syeikh Abdurrauf al-Singkili returned to Aceh from Haramain in the $17^{\text {th }}$ century, or approximately in 1661 A.D, after one of his teacher, al-Qusyasyi, passed away. ${ }^{3}$ During the colonization era of Dutch in Aceh, Tarekat developed well and became a threat for the colonial government due to its influence and role in fighting colonization.

It was a proof that Islamic organization had significant role on the war for the independence of Indonesia. Many Islamic organizations organized and mobilized people to fight against colonialism. ${ }^{4}$ One of those organization was Tarekat Syattariyah in Aceh that was led by Abu Habib Muda Seunagan, who fought the Dutch along with his students and followers. The Tarekat Syattariyah still develops nowadays in the area of Nagar Raya, Aceh, and has many followers. The existence of this Tarekat also had been discussed by Christian Snouck Hurgronje, a researcher who firstly studied about Tasawuf in Aceh. He explained that Tasawuf had been existed and developed since the $16^{\text {th }}$ century, and one of order of it was Tarekat Syattariyah, which was taught by Habib Muda Seunagan in Nagan Raya, Aceh. ${ }^{5}$

Tarekat Syattariyah existing in the regency of Nagan Raya was considered as an active religious order that developed well until recent days. This order had social welfare program and it actively involved in the social and political activities, even this order had significant role in political dynamic within the area of Nagan Raya. Thus, it made the phenomenon interesting to be studied further, particularly regarded the roles and influence of Tarekat Syattariyah Abu Habib Muda Seunagan within the political life in the regency of Nagan Raya. Then, this study was conducted under the title "The Influence of Tarekat Syattariyah (The Order of Islamic Mysticism of Syattariah) Toward Political and Social Aspects in Nagan Raya".

\section{Method:-}

This research was conducted as ethnographic study by using qualitative approach. The qualitative study referred to a study that the data was collected and stated in the form of statements and images, such as the interview result with informant. Then, the ethnographic study aimed to describe and to interpret the culture of certain social group of people. The ethnographic study focused on the pattern of activities, languages, believes, rituals, and ways of life. ${ }^{6}$

Ethnographic study referred to an empirical and theoretical approach used to gain description and deep analysis about culture, which based on intensive fieldwork. It made deep and thick description about commonality of complex structural concept, which included unspoken assumption that taken-for-granted in the life. An ethnographer focused on the details of local life, then associated it to the larger social process. An ethnographic cultural study concentrated on the qualitative study of values and meaning within the context of the way of living, which included cultures, life-words, and identity.

Tarekat Syattariyah Abu Habib Muda Seunagan And Its Influence Toward Social And Political Life Of The People In The Regency Of Nagan Raya:-

\footnotetext{
${ }^{2}$ Oman Fathurrahman, Tarekat Syattariyyah di Dunia Melayu-Indonesia (Kajian atas Dinamika dan Perkembangan Melalui Naskah- Naskah di Sumatera Barat, Disertasi Program Studi Ilmu Susastra Jakarta: Universitas Indonesia, 2003, p. 35.

${ }^{3}$ Oman Fathurahman, Tarekat Syattariyyah...,p. 47.

${ }^{4}$ Kamaruzzaman Bustamam-Ahmad, Islam Historis (Dinamika Studi Islam di Indonesia, Edisi Revisi, Yogyakarta: Jogja Bangkit Publisher, 2017, p. 243.

${ }^{5}$ Christian Snouck Hurgronje, De Atjehers, deel I en II, terj Sutan Maimoen, Aceh, Rakyat dan Adat Istiadatnya, Jakarta: INIS, 1997, p 10-16.

${ }^{6}$ Nana Syaodih Sukmadinata, Metode Penelitian Pendidikan, Jakarta: Program Pascasarjana Universitas

Pendidikan Indonesia dan PT. Remaja Rosdakarya, 2006, p. 62
} 
The term of Tarekat came from Arabic vocabulary: thariq, thariqah, ath-thariqu,thara'iq, which referred to the path, way, method, system, and order. Tarekat was defined as the path or way that was taken by a salik (the member and student of certain Tarekat) to get closer to God. ${ }^{7}$

It referred to certain method, way, or path that taken by a sufi (a person commended himself in the way of Islamic mysticism) to possess the highest spiritual achievement through the process of spiritual purification by reciting Zikir (prays to remember God). Tarekat then developed to be a religious social institution with solid membership. The essential parts of such institution were relationship between teacher and learner, relationship among learners, as well as the existence of norms and values that became foundation of those relationship. Actually, a Tarekat was an organization; Trimingham called it as Sufi Order, which based on the persistent obedience and fanatic toward teacher or mursyid. However, the main objective of such institution was leading to the spiritual obedience of God. ${ }^{8}$

The Tarekat was also the way that based on al-Quran and as-Sunnah (prophet's tenet). It orientated to the life in hereafter and focused on worship by obeying the command of God and preventing of His prohibition. The way in a Tarekat required guidance of a Syaikh or Mursyid (guiding teacher) through the process of Bai' at (pledge). ${ }^{9}$

The aforementioned explanation referred that a Tarekat referring to the path taken by a person, which consisted of collaboration of certain doctrines, method and rituals binding the followers under the aspects of Islam, such as Shalat (daily prays), fasting, zakat (obligatory tithe), Haji (pilgrimage to the holy city of Mecca during certain month with certain rituals), and so on. Furthermore, it also referred as a way to purify the soul through intensive zikir. A Tarekat also meant as an organization with top-down authority, which depended on the leadership of a mursyid.

The Tarekat Syattariyah was named after an Islamic scholar, Syaikh Abd Allah al-Syaththari (passed away in 1458 A.D), who was related to Shihab al-Din Abu Hafs Umar Suhrawardi (1145-1234 A.D) that developed the Tarekat Suhrawar-diyah. ${ }^{10}$ Tarekat Syattariyah was firstly developed in Iran and Transaxonia (middle Asia) with the name of Insyiqiah, and within the region of Turki Usmani with the name of Bistimiyah. It was named as Insyiqiah before its leading figure, Abu Yazid al-Isyqi. However, it was not affiliated to other sects of Islamic mysticism. This Tarekat had great influence within the area of India, Indonesia, Pattani, and Cam. It even had important role for the development of Islam in Indonesia, Malaysia, Pattani, and Thailand. ${ }^{11}$

In Aceh, it was Syaikh Abdurrahman As-Singkili, also known as Syiah Kuala, who introduced Tarekat Syattariyah. Around 1583-1660 A.D, in Mecca there was a great scholars in Islamic mysticism, Syeikh Shafiuddin Ahmad Ad Dajjani Al-Qusyasyi or also known as Syeikh Ahmad Al-Qusyasyi. Meanwhile, in Medina, there lived Syeikh Ibrahim al-Kurani, who was a follower and student of Syeikh Ahmad Al-Qusyasyi. Both scholars were teacher of Syeikh Abdurrauf As-Singkili; he pledged for Tarekat Syattariyah from both. Then, Abdurrauf As-Singkili developed Tarekat Syattariyah in Aceh, even it had spread within Indonesia. ${ }^{12}$

Tarekat Syattariyah still had great influence in Indonesia, even on the social and political aspect. In the province of Aceh, particularly in the regent of Nagan Rara, this Tarekat still existed and developed that the followers came from the entire area of Aceh.

Nagan Raya was a regent in the area of the Aceh with capital city of Suka Makmue, which located $287 \mathrm{~km}$ or six hours travelling by land form the capital city of Aceh, Banda Aceh. It was established on July 2, 2002 under the

\footnotetext{
${ }^{7}$ Abdul Wahid Mu'thi, Tarekat: Sejarah Timbul, Macam-macam, dan Ajarannya, dalam Diktat Kursus Tasawuf (Jakarta: Yayasan Wakaf Paramadina, 2006), p. 85-86

8 Agus Riyadi, Tarekat Sebagai Organisasi Tasawuf (Melacak Peran Tarekat Dalam Perkembangan

Dakwah Islamiah), Jurnal at-Taqaddum, Volume 6, Nomor 2, November 2014, p. 359-360.

${ }^{9}$ Sanusi, Tarekat dan Tasawuf, Surabaya: PT. Bina Ilmu, 1998, p. 57.

1010 Sri Mulyati, Mengenal dan Memahami Tarekat-Tarekat Muktabarah di Indonesia, (Jakarta: Kencana, 2006), p. 28

${ }^{11}$ Hawash Abdullah, Perkembangan Ilmu Tasawuf dan Tokoh-Tokoh di Nusantara (Surabaya: Penerbit Al-Ikhlas, 1996), p. 49.

${ }^{12}$ Ibid; p. 50.
} 
Regulations No. 22 of 2002 as the expansion of the West Aceh Regent. ${ }^{13}$ Several historical experts explained that his regent was formed under the area of three kingdoms:

1. The Kingdom of Seuneu'am Ujong Raja, which after the independence of Indonesia became the sub district of Darul Makmur with Alue Bilie as the capital city;

2. The Kingdom of Seunagan, which after the independence of Indonesia became the sub district of Seunagan with Jeuram as the capital city; and

3. The Kingdom of Beutong Banggalang, which after the independence of Indonesia became the sub district of Beutong with Alue Jalan (now Babussalam) as the capital city.

Those three kingdoms were the origin of the regency of Nagan Raya that the name Nagan was originated from the name of one kingdom. This regency was an expansion of the West Aceh regency in 2002, with Suka Makmur as capital city. ${ }^{14}$ Nagan Raya had 11 sub districts: Beutong, Darul Makmur, Kuala, Seunagan, Seunagan Timur, Tadu Raya, Kuala Pesisir, Suka Makmue, Tripa Makmur, Beutong Ateuh Banggalang, and Seuneuam. ${ }^{15}$

Abu Habib Muda Seunagan developed and taught his Tarekat at the sub district of Seunagan Timur, particularly in the village of Peuleukang, Nagan Raya. ${ }^{16}$ This Tarekat was named as Tarekat Syattariyah. ${ }^{17}$ His given name was Abu Habib Muda Seunagan mempunyai nama asli Habib Muhammad Yeddin bin Habib Muhammad Yasin bin Habib Abdurrahim Quthubul Ujud bin Habib Abdul Qadir Rama'any bin Said Athaf (intu); his bloodline was related to the prophet Muhammad p.b.u.h. Abu Habib Muda Seunagan was also known as Said Muhammad Yeddin, Abu Peulekung, Abu Nagan, Abu Bale, Abu Tuha, and Teungku Puteh. ${ }^{18}$ He was born at the village of Krueng Kulu, Blang Ara, Seunagan Timur in 1870. He was the $4^{\text {th }}$ child of 14 children in his family: ten male and four female. He had fought in several wars against the Dutch colonialism the army led by Habib Syaikhuna Muhammad Yasin, also known as Teungku Padang Si Ali, since he was young. ${ }^{19}$ Azman reported that Abu Habib Muda Seunagan was the descendant of the nine saints in Islam, who developed Islam in Java, yet Daniel argued this notion since there was no clear evidence about it. ${ }^{20}$

Abu Habib Muda Seunagan was known as a mursyid for Tarekat Syattariyah, which was introduced by Syeikh Abdurrauf bin Ali Al Jawi Al Singkily, also known as Syiah Kuala (1620-1693), who was a famous Islamic scholar

\footnotetext{
${ }^{13}$ The regent of Nagan Raya located in the western coastal area of Sumatera. It was a fertile area that suitably for cultivating rice, particularly in the sub district of Seunagan, Seunagan Timur, and Beutong, since there were two rivers supporting the plantation: Krueng Beutong and Krueng Nagan. Besides rice, the palm oil was also main commodity of this area. Since the great potency on the agricultural field, this area was known as a major rice producing area in Aceh. Even Soeharto, the former president of Indonesia, had visited this area in 1987 to appreciate the development of agriculture.

Before the conflict of Aceh, this area was the main destination for transmigration program. Yet, in 2001, most of transmigrants left this area for security reason. Then, after the reconciliation of Aceh, those transmigrants were expected to come again to this area for developing and supporting the economy of this newly established regent. https://id.wikipedia.org/wiki/Kabupaten_Nagan_Raya, accessed on February 22, 2016.

${ }^{14}$ Dinas Syariat Islam dalam Angka 2016, Maket Rencana Pembangunan Masjid Agung Kabupaten Nagan Raya di Kompleks Perkantoran, Nagan Raya: Dinas Syariat Islam, 2016, p.2

${ }^{15}$ Profile of the Nagan Raya Regent

${ }^{16}$ Peuleukang was a village in the territory of Seunagan Timur sub district. It was the forst settlement of Abu Habib Muda Seunagan, where he lived and taught Islam for the nearby people. He also struggled to fight colonialism from this village. Sehat Ihsan Shadiqin, Abu Habib Muda Seunagan, Republikan Sejati dari Aceh, Banda Aceh: Bandar Publishing, 2015, p.7

${ }^{17}$ Sepak Terjang dari Sosok Abu Habib Muda Seunagan, Serambi Indonesia, November 13, 2009 Edition.

${ }^{18}$ Hasan Basri, Perkembangan Thariqat Syattariyyah Desa Peulekung Kecamatan Seunagan Timur Kabupaten Nagan Raya, 1972-2014, Banda Aceh: Universitas Syiah Kuala, 2015, p. 3.

${ }^{19}$ Interview with Teuku Raja Keumangan (the head of the office of regional development) in 2015; he was also a candidate for regent of Nagan Raya for the period of 2017-2022, and the grandchild of Abu Habib Muda Seunagan.

${ }^{20}$ Daniel Andrew Birchok,Putting Habib Abdurrahim in His Place: Genealogy, Scale, and Islamization in Seunagan, Indonesia in Comparative Study in Society and History 2015 (p.497-527). Society for the Comparative Study of Society and History. Michigan: University of Michigan. 2015. p.503.
} 
in Aceh. ${ }^{21}$ When Abu Habib Muda Seunagan became leader in this Islamic mysticism order, the colonial called him Teungku Puteh, which referred to his courage that made his enemy afraid of him and also for his army and students who learned in the Tarekat Syattariyah under his guidance. ${ }^{22}$

Tarekat Syattariyah was firstly introduced and taught by Abu Habib Muda Seunagan in the village of Peulekung, sub district of Seunagan Timur, Nagan Raya. In the beginning, it only learned by the people in surrounding area, yet, the Tarekat then spread around Aceh. Lots of people came to learn about it and pledged as the followers for this Islamic order. They were interested in worshipping and became near to God, as the objective of this order was getting acquaintance and feeling the existence of God by using Ainul Bashirah (the supernatural eye). ${ }^{23}$ This order still exist in recent days and has lot of followers in Nagan Raya. ${ }^{24}$

The followers and students of this order had grown not only in the regent of Nagan Raya, but also in entire Aceh. Teuku Raja Azman explained, as quoted by Sammina Daud, that students of this order also taught similar Tarekat in several places in Aceh including in West Aceh (Kaway XVI, Panto Reu, and Pante Ceuremen), Southwest Aceh (Lama Inong), South Aceh (Labuhan Haji), Gayo (Blang Keujren), Southeast Aceh (Kuta Cane), and Pidie (Teupin Raya and Mon Keulayu near Garot). Teuku Azman also estimated that the followers of this order were about 50.000 people. $^{25}$

The research by Ismail (2016) also clarified that the followers of Abu Habib Muda Seunagan, or Abu Peulekung, not only were the inhabitant of Nagan Raya, but also came from the other regents in Aceh, such as West Aceh, Southwest Aceh, and Gayo Luwes. Those followers would came and gather celebrating Hari Raya Idul Adha (the holy day for commemorating the scarification of prophet Ismael). Meanwhile, they celebrated Hari Raya Idul Fitri (the holy day after a month fasting during Ramadhan, certain month in Islamic calendar) at their home land. The gathering and celebration together during Hari Raya Idul Adha made clear that this Tarekat had interested the people in Aceh. ${ }^{26}$

The relationship among followers were also really close, even they considered themselves as family. As an example, the followers from Pante Ceuremeen in West Aceh routinely visited the followers in Nagan Raya, especially in the village of Peulekung. They had kept this relationship for a long time. Even, the name of Pante Ceuremen (the mirror beach) was given by Abu Habib Muda Seunagan, since he assumed this location liked mirror in the middle of Meurebo River and Geunang Pulung River. ${ }^{27}$

The growth and development of this Tarekat could not be separated from the role of one political party in Indonesia: Partai Golongan Karya. This party intended to gain support from the followers of the Tarekat Syattariyah, since the majority people in West and South Aceh were followers of it. It was clear that this party needed the potency of followers of this order during the election. Then, there was also an assumption that if a political party gained support form an Islamic scholar, the followers from the scholar would also support the party. ${ }^{28}$

${ }^{21}$ Sepak Terjang dari Sosok Abu Habib Muda Seunagan, Serambi Indonesia, November 13, 2009 Edition.

${ }^{22}$ AntaraAceh, Kiprah Abu Habib Muda Seunagan Merebut Kemerdekaan, November 10, 2015 Edition. (http://aceh.antaranews.com/berita/27487/kiprah-abu-habib-muda-seunangan-merebut-kemerdekaan)

${ }^{23}$ Mustafa Zahri, Kunci Memahami Tasawuf...,p. 86.

${ }^{24}$ Misri A. Muchsin, Dinamika Tasawuf di Aceh..., p. 174.

${ }^{25}$ Sammina Daud, Abu Habib Muda Seunagan \& Tarikat Syattariyah, Jakarta: Karya Sukses Sentosa, 2009. p. 32.

${ }^{26}$ Ismail, Melacak Metode Penentuan Awal Bulan Hijriah Pengikut Abu Peuleukung Nagan Raya (Analisis Penetapan 1 Ramadhan, 1 Syawal dan 10 Zhulhijjah), Penelitian 2016. Pusat Studi Ilmu Falak IAIN Lhoksemawe

${ }^{27}$ Ibrahim Husein, SE, 50 years old, entrepreneur, lived in Pante Ceureumen, Burhanuddin,54 years old, retiree of government worker, lived in Pante Ceureumen, Zaini Has, SE, 45 years old, staff in the office of sub district in Pante Ceureumen, lived in Gampong Manjeng; and Abdul Hamid, 46 years old, an officer of Wilayatul Hisbah (the office for Islamic law enforcement) in Pante Ceureumen, lived in Gampong Pante Ceureumen, Sejarah Terbentuknya Kecamatan Pante Ceureumen Kabupaten Aceh Barat, (http://panteceureumen.acehbaratkab.go.id/profil/sejarah) accessed on February 22, 2016.

${ }^{28}$ Duski Samad, Politik dan Tarekat (Dukungan Politik Kaum Syathariyah), IAIN Imam Bonjol Padang, tt. See also private website of Prof. Duski Samad, M. Ag (Professor of Islamic Mysticism at IAIN 
In Aceh, it could not be denied that Ulama (Islamic scholar) had important role in politics. Ulama also took part in the history of Aceh. Then, Abu Hahib Muda Seunagan also had important role in the political and historical dynamic in the area of West Aceh. He fought the Dutch colonization and also took part in the struggle against Japan invasion during World War II. Even he was a victim during the war against Japan. ${ }^{29}$ During the beginning time of the independence of Indonesia, Abu Habib Muda Seunagan stated his loyalty to the government of Indonesia. Some oral stories, it was recorded in the biography of Habib Muda Seunagan, told that Habib was invited by the first president to the capital city of Indonesia as a gratitude of his loyalty. ${ }^{30}$ Even he mobilized his followers and students to keep the security during this era. Then, during the era of Orde Baru (New Order) governance, he was the first scholars supporting the major political party, Golongan Karya. This party had the authority in determining the development of Indonesia during that time. ${ }^{31}$ Then, the participation of Abu Habib Muda Seunagan also had contribution for the result of national election in 1977 that the Golongan Karya won the majority of vote in Aceh. Abu Habib Muda Seunagan was the first Islamic scholar who became the member of this party, and as he became the member, 25.000 of his students and followers in South and West Aceh also enrolled as the member of this party. ${ }^{32}$ Therefore, the participation of Abu Habib Muda Seunagan in political field made Golongan Karya had great influence toward the area of Nagan Raya since 2002 until 2017. Even in the national election in 2006 and 2012, Golongan Karya gained absolute vote from the people of Nagan Raya. It made us realized the influence and role of Islamic order toward political field in Aceh, particularly in Nagan Raya.

Some people might think that those who followed and became member of certain Islamic mysticism order were tended to restrain themselves of earthly matters. Yet, this assumption was not really accurate. As example, in Padang Pariaman, an area in the province of West Sumatera, the followers of Islamic mysticism order involved themselves in practical politics. Furthermore, it was common in Indonesia that the authorities such as minister, the General of the Army, and political figures visited the leader of Islamic mysticism order. ${ }^{33}$ Such case also occurred in Nagan Raya. Tarekat Syattariyah existing and developing in this area involved in practical politics within this area. Abu Habib Muda Seunagan as the Mursyid of this order even was the member of a political party, Golongan Karya.

In the area of Nagan Raya, the influence of Tarekat Syattariyah was greatly realized by the people within this area. It was noted that the political matter was led by only certain people, in this case was the member of family of Abu Habib Muda Seunagan. ${ }^{34}$ Since the establishment of this regency as the expansion of the West Aceh Region in 2002 , this regency was led by T. Zulkarnaini, also known as Ampon Bang, who was a member of Tarekat Syattariyah and the family of Abu Habib Muda Seunagan. In the initial era of the establishment, 2002-2006, he was chosen by the government as an incumbent regent for this regency. Then, for the period of 2007-2012, he won the election as the regent with Muhammad Kasim Ibrahim as the vice regent. Ampon Bang also won the election for 2012-2017 period as the regent with Djamin Idham as his vice regent. Thus, he had led this regency for three periods in total.

This success of Ampon Bang in political field indicated that the role of certain people was great within the area of Nagan Raya. It was acclaimed by a research in 2014 stating that political dynamic in Nagan Raya was drove by certain social groups. This research also indicated that the people of Nagan Raya was divided into three social

(State Institute of Islamic Studies) Imam Bonjol Padang), Politik dan Tarekat, (Dukungan Politik Kaum Syathariyah) (https://profduski. wordpress.com/2016/01/03/politik-tarekat/)

${ }^{29}$ Sehat Ihsan Shadiqin, dkk, Abu Habib Muda Seunagan Republiken Sejati dari Aceh, Banda Aceh: Bandar Publishing, 2015, p.3-5.

${ }^{30}$ See also Daniel Andrew Birchok,Putting Habib Abdurrahim in His Place: Genealogy, Scale, and Islamization in Seunagan, Indonesia in Comparative Study in Society and History 2015 (p.497-527).

Society for the Comparative Study of Society and History. Michigan: University of Michigan. 2015. p.503.

${ }^{31}$ Sehat Ihsan Shadiqin, dkk, Abu Habib Muda Seunagan..., p. 5.

${ }^{32}$ Interview with Mak Tuha (a resident of Ule Jalan Beutong), February 28, 2017.

${ }^{33}$ Sadri Chaniago and Nidzam Sulaiman, Partisipasi Politik Tuanku Tarekat Syattariyah Dalam Partai Nasionalis di Padang Pariaman, Sumatera Barat, a paper presented at the seminar of "International Conference on Islam in the Malay World," Bandung, Indonesia, November 20-22, 2011. Performed by Program Pascasarjana UIN Sunan Gunung Djati Bandung (PPs UIN SGD) collaborated with Akademi Pengajian Islam Universiti Malaya (APIUM) Malaysia, p. 3.

${ }^{34}$ The certain people referred to the noble family of Ulama and the descendants of king in Nagan Raya 
groups as Ulee Balang (noble family, in Aceh they had Teuku as the first name), Said or Habib (descendants of the Ulama), and common people. ${ }^{35}$

Teuku Zulkarnaini, also known as Ampon Bang, had the bloodline of noble family as he was related to the $6^{\text {th }}$ king of Beutong Kingdom, and also had the bloodline of Ulama, as he related to Abu Habib Muda Seunagan. He actually was the grandchild of the $6^{\text {th }}$ king of Beutong as well as the grandchild of Abu Habib Muda Seunagan. ${ }^{36}$ Referring to the fact that he came from noble family, it was realized that his success upon political field was influenced by his family and bloodline. Furthermore, the most influencing party in this case was Tarekat Syattariyah, which had many followers in entire Nagan Raya. It also supported by the fact that the followers and students of this Islamic mysticism order really obeyed the teacher or mursyid; if the mursyid had stated to choose certain figure for election, the followers would have chosen as stated by him.

Teuku Zukarnini was the grandchild of Abu Habib Muda Seunagan, as well as a member in Golongan Karya Party, a party that supported by his grandfather, Abu Habib Muda Seunagan. ${ }^{37}$ This fact revealed the great influence of the Abu Habib Muda Seunagan's family toward practical politics in the area of Nagan Raya. Even not only Teuku Zulkarnaini had strategic position in the government, several members of his family also had strategic position in determining the establishment and the development of Nagan Raya. The people of Nagan Raya supported them expecting the change and devilment toward better condition in their regency. The majority of support indeed came from the followers and students of Tarekat Syattariyah.

Then, in the regional election of 2014, Golongan Karya got seven position in the City Representative, and two of those position was held by wife and brother of Teuku Zulkarnaini. Teuku Zukarnaini as the leader of Golongan Karya Party recommended his wife to be elected as the chairperson of city representative for the period of 20142019. It also occurred by the influence of the followere of Tarekat Syattariyah trusting the descendants of Abu Habib Muda Seunagan in leading Nagan Raya. ${ }^{38}$ Students of followers of this Islamic order also believed that Golongan Karya party was supported by Abu Habib Muda Seunagan since this party was based on Pancasila (Five Principles on Indonesian Ideology) and The Indonesia constitution which contained the value of Islam. Thus, by electing this party, it would ensure the stability upon religious life. ${ }^{39}$

Until nowadays, the majority of those had position in the governance came from the member of Golongan Karya party, and they fully supported all policy from government. It was also influence by the participation of Tarekat Syattariyah toward practical politics in this area. The choice of mursyid in this Islamic mysticism order would determine the winner in the election, both in legislative and executive election. It was supported by the fact that Teuku Zulkarnaini had been the leader of this region for three periods, since the establishment of this regency in 2002. It also proofed the close relationship of the followers and students of this order that they unified to achieve certain objectives together, eventhough with sacrifice.

\section{The Loss of Tarekat Syattariyah in the Election of 2017:-}

It was interesting case that the influence of this Islamic mysticism order had been weakening. There were several factors causing such occasion. Firstly, the people of Nagan Raya lost their trust upon the leadership of Teuku Zulkarnaini. During his governance, he tended building a dynasty of governance consisting only his family, or he committed nepotism. He inaugurated the member of his family member in several strategic position in the government of Nagan Raya. Actually, it had neglected the expectation of the people about good governance, which they expected would be realized by the family of Abu Habib Muda Seunagan. Then, Teuku Zulkarnaini also frequently changed several officials because they did not want to compromise with this regent. ${ }^{40}$

\footnotetext{
${ }^{35}$ Interview with Abdul Kadir (The head of the office of Islamic law affair of Nagan Raya), March 27, 2016.

${ }^{36}$ Cut Nurul Hayati, Politik Berasaskan Kaum...,p. 31-33.

${ }^{37}$ Interview with Rahmad Syahputera, a student of graduate program of UIN (State University on Islamic Studies) Ar-Raniry, Banda Aceh. February 23, 2017.

${ }^{38}$ Interview with ZA. Arifin, a inhabitant of Suak Puntong in Nagan Raya, March 28, 2016

${ }^{39}$ Interview with Sehat Ihsan Shadiqin during the presentation of his proposal about the development of Tarekat in southern and western Aceh. Banda Aceh

${ }^{40}$ Harian Rakyat Aceh, Kokoknya Dinasti Ampon Bang, June 1, 2015 Edition. See also the website http://rakyataceh.co/2015/06/kokohnya-dinasti-ampon-bang/
} 
Secondly, during 13 years of his leadership, Teuku Zulkarnaini was found as an authoritarian person. The election of his wife, Kelimah, as the chairperson for Nagan Raya in November 15, 2014 made a new history that a regency was led by a spouse in legislative and executive position. Kelimah, also familiarly called as Mak Gayo, was a legislative candidate from Golongan Karya party, a party that also led by Teuku Zulkarnaini. Mak Gayo won the election as the chairperson in legislative board absolutely, and inaugurated for the period of $2014-2019 .^{41}$ This occasion made the people realized that Teuku Zulkarnaini tried to build a dynasty consisting of his family in the government of Nagan Raya.

As the impact, in the regional election of 2017, Teuku Raja Keumangan as the candidate from Golongan Karya party for the regent of Nagan Raya for the period of 2017-2022 was lost. Teuku Raja Keumangan was the little brother of Teuku Zulkarnaini, and also the grandchild or Abu Habib Muda Seunagan. The people of Nagan Raya lost their trust upon this family due the nepotism committed during their governance. ${ }^{42}$ It also indicated that the people of Nagan Raya had understood the political strategy played by that family. This loss made Tarekat Syattariyah had to consider again their strategy on practical politics in the future.

\section{Summary:-}

Tarekat Syattariyah located in the village of Peuleukung in subdistrict of Seunagan Timur, Nagan Raya was introduced and taught by Abu Habib Muda Seunagan. It had great influence toward practical politics in this area. The member of family of Abu Habib Muda Seunagan had strategic positions. It was proofed by the fact that since the establishment of this region in 2002, the regent was descendant of Abu Habib Muda Seunagan. However, since the leader committed nepotism, the people of Nagan Raya did not trust the family of Abu Habib Muda anymore. The loss of Teuku Raja Keumangan, brother of Teuku Zulkarnaini, as the candidate for regent in 2017 proofed that the people had lost their trust. It occurred since Teuku Zulkarnani tried to build dynasty of his family during his leadership for three periods.

\section{References:-}

1. Abdul Wahid Mu'thi, (2006). Tarekat: Sejarah Timbul, Macam-macam, dan Ajarannya, dalam Diktat Kursus Tasawuf, Jakarta: Yayasan Wakaf Paramadina.

2. Agus Riyadi, (2014) Tarekat Sebagai Organisasi Tasawuf (Melacak Peran Tarekat Dalam Perkembangan Dakwah Islamiah), Jurnal at-Taqaddum, Volume 6, Nomor 2, November 2014.

3. Antara Aceh, (2015). Kiprah Abu Habib Muda Seunagan Merebut Kemerdekaan, Edisi 10 November 2015.

4. Christian Snouck Hurgronje, (1977). De Atjehers, deel I en II, terj Sutan Maimoen, Aceh, Rakyat dan Adat Istiadatnya, Jakarta: INIS.

5. Daniel Andrew Birchok, Putting Habib Abdurrahim in His Place: Genealogy, Scale, and Islamization in Seunagan, Indonesia in Comparative Study in Society and History 2015 (p.497-527). Society for the Comparative Study of Society and History. Michigan: University of Michigan. 2015.

6. Cut Nurul Hayati, (2014). Politik Berasaskan Kaum di Nagan Raya (Suatu Penelitian Tentang Strategi Pemenangan T. Zulkarnaini dalam Pemilukada 2012-2017), Banda Aceh: Fakultas Sosial dan Ilmu Politik Universitas Syiah Kuala. tidak diterbitkan.

7. Dinas Syariat Islam dalam Angka 2016, Maket Rencana Pembangunan Masjid Agung Kabupaten Nagan Raya di Kompleks Perkantoran, Nagan Raya: Dinas Syariat Islam.

8. Duski Samad, (2016). Politik dan Tarekat (Dukungan Politik Kaum Syathariyah), IAIN Imam Bonjol Padang, tt. Lihat juga pada website pribadi Prof. Duski Samad, M. Ag (Guru Besar Ilmu Tasawuf IAIN Imam Bonjol Padang), Politik dan Tarekat, (Dukungan Politik Kaum Syathariyah) (https://profduski.wordpress.com/ 2016/01/03/politik-tarekat/).

9. Harian Rakyat Aceh, Kokoknya Dinasti Ampon Bang, Edisi 1 Juni 2015. Atau lihat juga pada Website resmi http://rakyataceh.co/2015/06/kokohnya-dinasti-ampon-bang/

10. Hasan Basri, (2015). Perkembangan Thariqat Syattariyyah Desa Peulekung Kecamatan Seunagan Timur Kabupaten Nagan Raya, 1972-2014, Banda Aceh: Universitas Syiah Kuala. Tidak diterbitkan.

\footnotetext{
${ }^{41}$ Interview with Mr. Rais (the secretary of The Acehnese Cultural Board of Nagan Raya) February 28, 2017.

${ }^{42}$ Interview with Maulidin, a student in Faculty of Dakwah and Communication of UIN Ar-Raniry and the former leader of the Association of Students of Sub District Kuala, Nagan Raya, March 1, 2017.
} 
11. Hawash Abdullah, (1996), Perkembangan Ilmu Tasawuf dan Tokoh-Tokoh di Nusantara, Surabaya: Penerbit Al-Ikhlas.

12. Ismail, (2016). Melacak Metode Penentuan Awal Bulan Hijriah Pengikut Abu Peuleukung Nagan Raya (Analisis Penetapan 1 Ramadhan, 1 Syawal dan 10 Zhulhijjah), Penelitian 2016. Pusat Studi Ilmu Falak IAIN Lhoksemawe.

13. Kamaruzzaman Bustamam-Ahmad, (2017). Islam Historis (Dinamika Studi Islam di Indonesia, Edisi Revisi, Yogyakarta: Jogja Bangkit Publisher.

14. Misri A. Muchsin, (2012), Dinamika Tasawuf di Aceh Pada Abad Ke 20, Kajian Sejarah, Sosial dan Keagamaan, Cet 1, Banda Aceh: Ar-Raniry Press dan Lembaga Naskah Aceh (NASA).

15. Mustafa Zuhri, (1998). Memahami Ilmu Tasawuf, Surabaya: PT. Bina Ilmu (BI).

16. Nana Syaodih Sukmadinata, (2006). Metode Penelitian Pendidikan, Jakarta: Program Pascasarjana Universitas Pendidikan Indonesia dan PT. Remaja Rosdakarya.

17. Oman Fathurrahman, (2003). Tarekat Syattariyyah di Dunia Melayu-Indonesia (Kajian atas Dinamika dan Perkembangan Melalui Naskah- Naskah di Sumatera Barat, Disertasi Program Studi Ilmu Susastra Jakarta: Universitas Indonesia.

18. Sadri Chaniago dan Nidzam Sulaiman, (2011). Partisipasi Politik Tuanku Tarekat Syattariyah Dalam Partai Nasionalis di Padang Pariaman, Sumatera Barat, Makalah yang dipresentasikan dalam "International Conference on Islam in the Malay World," Bandung, Indonesia, 20-22 November 2011. Diselenggarakan oleh Program Pascasarjana UIN Sunan Gunung Djati Bandung (PPs UIN SGD) bekerjasama dengan Akademi Pengajian Islam Universiti Malaya (APIUM) Malaysia.

19. Sammina Daud, (2009). Abu Habib Muda Seunagan \& Tarikat Syattariyah, Jakarta: Karya Sukses Sentosa.

20. Sanusi, (1998). Tarekat dan Tasawuf, Surabaya: PT. Bina Ilmu.

21. Sehat Ihsan Shadiqin, dkk, (2015). Abu Habib Muda Seunagan, Republiken Sejati dari Aceh, Banda Aceh: Bandar Publishing.

22. Sepak Terjang Dari Sosok Abu Habib Muda Seunagan, Serambi Indonesia Edisi 13 November 2009.

23. Sri Mulyati, (2006). Mengenal dan Memahami Tarekat-Tarekat Muktabarah di Indonesia, Jakarta: Kencana.

\section{Interviews:-}

1. Interview with Abdul Kadir (The head of the office of Islamic law affair of Nagan Raya), March 27 , 20

2. Interview with Abu Qudrat (Mursyid in Tarekat Syattariyah Abu Habib Muda Seunagan).

3. Interview with Asri (Follower of Tarekat Syattariyah Abu Habib Muda Seunagan).

4. Interview with Ainal Marziah inhabitant of Ulee Jalan Beutong on Februari 27, 2016.

5. Interview with Ainal inhabitant of Beutong, Nagan Raya on Februari 27, 2017.

6. Interview with Husaini Husda (a historian in Nagan Raya) also supported by Interview with Mr. Rais the secretary of The Acehnese Cultural Board of Nagan Raya) February 28, 2017.

7. Interview with Mak Tuha, (inhabitant of Ulee Jalan, Beutong), Februari 28, 2016.

8. Interview with Maulidin a student in Faculty of Dakwah and Communication of UIN Ar-Raniry and the former leader of the Association of Students of Sub District Kuala, Nagan Raya, March 1, 2017. Supported by interview with Syarifah, inhabitant of Beutong Nagan Raya, March 1, 2017.

9. Interview with Pak Rais (the secretary of The Acehnese Cultural Board of Nagan Raya) February 28, 2017.

10. Interview with Rahmad Syah, a student of graduate program of UIN (State University on Islamic Studies) Ar-Raniry, Banda Aceh. February 23, 2017.

11. Interview with Sayed Akhir Zaman (Khalifah Thariqat Syatharriyah) in Nagan Raya.

12. Interview with Sehat Ihsan Shadiqin during the presentation of his proposal about the development of Tarekat in southern and western Aceh. Banda Aceh February 16, 2017.

13. Interview with Syarifah, inhabitant of Beutong Nagan Raya, Februari 28, 2017.

14. Interview with Teuku Raja Keumangan Teuku Raja Keumangan (the head of the office of regional development) in 2015; he was also a candidate for regent of Nagan Raya for the period of 20172022, and the grandchild of Abu Habib Muda Seunagan.

15. Interview with ZA. Arifin an inhabitant of Suak Puntong in Nagan Raya, March 28, 2016

16. Interview with Zainal Arifin, a teacher in West Aceh, Pada 6 Maret 2016. 
17. Interview with Mak Tuha, (inhabitant of Ulee Jalan, Beutong), Februari 28, 2016.

18. Interview with Ibrahim Husein, SE, 50 years old, entrepreneur, lived in Pante Ceureumen, Burhanuddin, 54 years old,retiree of government worker, lived in Pante Ceureumen

19. Interview with Zaini Has, SE, 45 years old, staff in the office of sub district in Pante Ceureumen, lived in Gampong Manjeng; and

20. Interview with Abdul Hamid, 46 years old, an officer of Wilayatul Hisbah (the office for Islamic law enforcement) in Pante Ceureumen, lived in Gampong Pante Ceureumen, Sejarah Terbentuknya Kecamatan Pante Ceureumen Kabupaten Aceh Barat

\section{Relating Website:-}

1. http://panteceureumen.acehbaratkab.go.id/profil/sejarah) diakses pada 22 Februari 2016.

2. https://id.wikipedia.org/wiki/Kabupaten_Nagan_Raya diakses pada 22 Februari 2016.

3. (http://aceh.antaranews.com/berita/27487/kiprah-abu-habib-muda-seunangan-merebut-kemerdekaan) 